\title{
PENGARUH MEDIA PEMBELAJARAN BERBASIS TIK TERHADAP MOTIVASI BELAJAR
}

\author{
Muhammad Fajrin \\ Dosen FKIP Universitas Tanjungpura Pontianak \\ daengmeraja@yahoo.com
}

\begin{abstract}
ABSTRAK
Penelitian tentang Pengaruh Media Pembelajaran Berbasis Teknologi Informasi dan Komunikasi Terhadap Motivasi Belajar. Penelitian ini dilakukan terhadap peserta didik kelas sepuluh pada mata pelajaran ekonomi. Penelitian ini dilakukan untuk mengetahui pengaruh penggunaan media pembelajaran berbasis Teknologi Informasi dan Komunikasi terhadap motivasi belajar peserta didik. Penelitian ini adalah kuasi eksperimen dengan bentuk nonequivalent control group design. Berdasarkan uji normalitas, homogenitas, dan uji t dari data pretes-postes motivasi belajar peserta didik kelas eksperimen dapat disimpulkan bahwapertamaterdapat perbedaan motivasi belajar peserta didik antara sebelum dan sesudah perlakuan pada kelas eksperimen yang menggunakan media pembelajaran berbasis TIK. Kedua, terdapat perbedaan motivasi belajar peserta didik antara sebelum dan sesudah perlakuan pada kelas kontrol yang menggunakan media grafis. Ketiga, tidak terdapat perbedaan peningkatan motivasi belajar peserta didik antara kelas eksperimen yang menggunakan media pembelajaran berbasis TIK dengan kelas kontrol yang menggunakan media grafis.
\end{abstract}

Kata Kunci: kuasi eksperimen, TIK, motivasi belajar

\section{ABSTRACT}

Research on the Effect of Instructional Media and Information CommunicationTechnology Based Learning Motivation. This research wasconducted on the tenth grade studentson economic subjects. This study was conductedtodetermine the effect ofthe use ofmedia-based learning of ICTon the motivationof learners. Thisis aquasi-experimentalstudywithnonequivalentcontrol group designform. Based test the for normality, homogenity, and the t testofthe datapretest-posttest motivationof learners classroom experiments canbe concludedthat the first differencesof learners' learning motivation betweenbefore and after treatment in experimental classes using ICTbased learning media. Second, there are differences between thelearners' learning motivation before and after treatment in the control class using graphic media. Third, there is no difference increased motivationof learners between the experimenta lclasses using ICT-based learning with media control classthatuses graphic media.

Keywords: quasi-experiments, ICT, learning motivation

\section{PENDAHULUAN}

Rendahnya motivasi belajar peserta didik dalam mata pelajaran ekonomi sebagai akibat dari karakteristik mata pelajaran ekonomi yang didasarkan pada fenomena empirik yang rasional dipengaruhi oleh proses belajar mengajar (PBM). Berdasarkan praktiknya PBM mengandung lima komponen komunikasi (Daryanto, 2011:5), diantaranya adalah pendidik sebagai komunikator, adanya bahan pembelajaran sebagai informasi yang akan disampaikan, penggunaan media dalam pembelajaran sebagai sarana komunikasi, adanya peserta didik sebagai komunikan, dan adanya tujuan pembelajaran sebagai pedoman evaluasi hasil belajar. Rendahnya motivasi belajar mengisyaratkan adanya masalah dalam PBM, termasuk permasalahan dalam komponen komunikasi. Kesemua ini adalah penyebab yang bisa mengakibatkan rendahnya motivasi belajar. Permasalahan umum dalam penelitian ini adalah bagaimana pengaruh media pembelajaran berbasis teknologi informasi dan komunikasi (TIK) terhadap motivasi belajar. Untuk menghidari masalah yang terlalu luas, maka Penulis merumuskan masalah umum menjadi subsub masalah sebagai berikut: Pertama, apakah terdapat perbedaan motivasi belajar peserta didik antara sebelum dan sesudah 
perlakuan pada kelas eksperimen yang menggunakan media pembelajaran berbasis TIK? Kedua, apakah terdapat perbedaan motivasi belajar dan pemahaman peserta didik antara sebelum dan sesudah perlakuan pada kelaskontrol yang menggunakan media grafis? Ketiga, apakah terdapat perbedaan peningkatan motivasi belajar peserta didik pada kelas eksperimen yang menggunakan media pembelajaran berbasis TIK dengankelaskontrol yang menggunakan media grafis?. Tujuan penelitian ini untuk mengetahui pengaruh media pembelajaran berbasis TIK terhadap motivasi belajar peserta didik.Media pembelajaran berbasis TIK jika ditinjau berdasarkan teori kontruktivisme yang dipelopori oleh Piaget, Bruner, dan Vygotsky ini memandang bahwa pengetahuan dan pemahaman yang akan diperoleh harus dilakukan dengan aktivitas pengalaman personal dan eksperimental (Rusman, et al. 2011:35), Teori tersebut, menurut Ertmen dan Newby merupakan teori belajar yang mendasari pembelajaran berbasis TIK. Sebuah penelitian tentang persepsi pendidik dalam pemanfaatan TIK untuk mengajar, untuk pengembangan profesi, administrasi, dan penggunaan pribadi menginformasikan bahwa sebagian besar pendidik yang diteliti mengakui bahwa TIK memiliki dampak positif terhadap peserta didik dalam pembelajaran Mwalongo A, (2011:45), Heafner, T (2004:49). Joshua E. Susskind (2006:9), dan Saiful Bahri (2011:146) membuktikan bahwa media pembelajaran berbasis TIK berpengaruh terhadap peningkatan motivasi belajar peserta didik.hal ini memungkinkan untuk meningkatkan motivasi belajar dan meningkatan pemahaman konsep peserta didik dalam mata pelajaran ekonomi jika menggunakan media pembelajaran berbasis TIK dalam PBM.Konsep motivasi jika dikaitkan dengan tingkah laku seseorang maka konsep tersebut tergambar jika seseorang senang terhadap sesuatu, apabila ia dapat mempertahankan rasa senangnya maka akan termotivasi untuk melakukan kegiatan itu, dan apabila seseorang merasa yakin dengan kemampuannya untuk mengahadapi tantangan maka biasanya orang tersebut terdorong melakukan kegiatan tersebut (Hamzah, 2009:8). Strategi motivasi yang dapat digunakan pendidik dalam memproduktifkan pesertadidik dalam belajar dapat dilakukan dengan menghubungkan materi pelajaran dengan kondisi lingkungan, kondisi tingkat kesukaran, kondisi belajar yang bermakna, dan pengganggu strategi bermakna.Upayalainuntukmemproduktifkan peserta didik dapat dilakukan juga dengan memberi harapan untuk berhasil, berisi kesuksesan program, tujuan pengajar, remedial sosialisasi perhargaan dari luar yang dapat berisi hadiah, kompetensi yang positif, dan nilai hasil belajar (Brophy dalam Hamzah, 2009:8). Motivasi memiliki peran penting dalam belajar dan pembelajaran diantaranya adalah menentukan hal-hal yang dapat dijadikan penguatan belajar dengan cara menghadapakan peserta didik dengan masalah-masalah yang kemudian harus dicarikan solusi berdasarkan pengetahuan dan pengalaman yang dimiliki peserta didik (Hamzah, 2009:27). Hakikat motivasi belajar adalah bentuk dorongan internal dan eksternal terhadap peserta didik yang sedang mengikuti PBM untuk mengadakan perubahan tingkah laku (Hamzah, 2009:31) sehingga indikator motivasi belajar dirumuskan sebagai berikut: (1) meliputi adanya hasrat dan keinginan untuk berhasil, (2) adanya dorongan dan kebutuhan dalam belajar, (3) adanya harapan dan cita-cita masa depan, (4) adanya penghargaan dalam belajar, (5) adanya kegiatan yang menarik dalam belajar, (6) adanya lingkungan belajar yang kondusif sehingga memungkinkan peserta didik dapat belajar dengan baik.Heafner, T (2004:43) dalam penelitiannya yang berjudul "Using Technology To Motivate Students To Learn Social Studies" menggunakan model motivasi yang dikembangkan oleh Pintrich dan Schunk pada tahun1996 (Heafner, T. 
2004:43) dengan indikator terdiri dari Expectancy dan Value. Hasil penelitian ini menggambarkan bahwa pemanfaatan teknologi dalam PBM dapat meningkatkan motivasi belajar peserta didik (Heafner, T. 2004:49). Expectancy and Value Model Of Motivational Theory ini terdiri dari tiga indikator yaitu Expectancy, Value, dan affective. Model ini terdapat dalam Motivated Strategies for Learning Questionnaire (MSLQ) yang dikembangkan oleh Pintrich, P.R., Smith, D.A., Garcia, T., \& McKeachie W.J. pada tahun 1991.Berkaitan dengan motivasi belajar peserta didik, maka instrumen yang sesuai terdiri dari enam indikator yaitu Intrinsic Goal Orientation adalah memiliki orientasi tujuan terhadap tugas akademik yang menunjukkan partisipasi peserta didik dalam tugas dan ini adalah tujuan akhir. Selain itu partisipasi peserta didik dalam tugas karena alasanalasan seperti tantangan, rasa ingin tahu, dan penguasaan (Howey, S. C. 2008). Extrinsic Goal Orientation menyangkut sejauh mana peserta didik merasa dirinya akan berpartisipasi dalam tugas karena alasanalasan seperti nilai, penghargaan, evaluasi kinerja orang lain, dan persaingan. Peserta didik yang memiliki orientasi tujuan ekstrinsik yang tinggi akan terlibat dalam tugas-tugas belajar sebagai sarana untuk mencapai tujuan. Perhatian utama di sini adalah bahwa peserta didik dengan Orientasi Goal ekstrinsik tinggi berhubungan dengan isu-isu selain yang langsung berhubungan dengan berpartisipasi dalam tugas itu sendiri (Howey, S. C. 2008). Task Value mengacu pada evaluasi peserta didik tentang ketertarikannya dan kepentingannya akan tugas yang ada. Tingginya nilai tugas mengarah pada keterlibatan yang lebih banyak dalam belajar. Nilai tugas mengacu pada persepsi peserta didik tentang materi kuliah dan kebermanfaatan (Howey, S. C. 2008). Control of Learning Beliefs adalah keyakinan peserta didik tentang upaya mereka untuk belajar akan menghasilkan hasil yang positif. Ini menyangkut keyakinan bahwa hasil belajar tergantung pada usaha sendiri, berbeda dengan faktor-faktor eksternal seperti pendidik. Jika peserta didik percaya bahwa upaya mereka untuk belajar membuat perbedaan dalam pembelajaran mereka, mereka harus lebih cenderung untuk mempelajari lebih strategis dan efektif. Artinya, jika peserta didik merasa bahwa mereka dapat mengontrol kinerja akademis mereka, mereka lebih mungkin untuk mengemukakan upaya untuk mempengaruhi perubahan yang diinginkan (Howey, S. C. 2008). Self-Efficacy for Learning and Performance terdiri dari dua aspek harapan: harapan untuk sukses dan self-efficacy. Harapan untuk sukses mengacu pada ekspektasi kinerja, dan berhubungan secara khusus untuk kinerja tugas. Self-efficacy adalah penilaian kemampuan pribadi dalam menyelesaikan tugas dan kepercayaan diri dalam memiliki keterampilan yang dibutuhkan untuk melakukan tugas (Howey, S. C. 2008). Test Anxiety telah ditemukan berhubungan negatif dengan harapan serta prestasi akademis. Tes kecemasan terdiri dari dua indikator yaitu khawatir dan emosional. Komponen khawatir mengacu pada pikiran negatif siswa yang mengganggu kinerja, sedangkan komponen emosionalitas mengacu pada aspek afektif dan gairah fisiologis. Keprihatinan kognitif dan keasyikan dengan kinerja telah ditemukan untuk menjadi sumber terbesar dari penurunan kinerja. Pelatihan dalam penggunaan strategi pembelajaran yang efektif dan ujian keterampilan harus membantu mengurangi tingkat kecemasan (Howey, S. C. 2008). Penelitian yang berjudul Pengaruh Media Pembelajaran Berbasis Teknologi Informasi Dan Komunikasi Terhadap Motivasi Belajar akan dijawab dengan metode quasi eksperimental design dengan bentuk nonequivalent control group design yang akan dilakukan pada kelas X.Sistematika penulisan terdiridari pendahuluan, metode penelitian, hasil dan pembahasan, 
kesimpulan.

\section{METODE PENELITIAN}

Penelitian ini adalah quasi eksperimen dengan menggunakan design nonequivalent control group design. Penelitian terdiri dari kelas eksperimen dan kelas kontrol yang dilakukan pada pelajaran ekonomi dikelas X SMA Kartika Siliwangi-2 Bandung. Indikatoralat tes untuk motivasi belajar diadaptasi dari Motivated Strategies for Learning Questionnaire (MSLQ) yang diadaptasi dari Pintrich, PR and De Groot V (1990:40), Pintrich, P.R., Smith, D.A., Garcia, T., \&McKeachie W.J. padatahun 1991 (Cahterin, 2002:15), Pintrich, PR pada 1996 (Heafner, T. 2004:43).Teknik Analisis Data menggunakan gain ternormalisasi. Seperti yang diungkapkan oleh Hake (2002:3) bahwa dengan mendapatkan nilai rata-rata gain yang ternormalisir maka secara kasar akan dapat mengukur efektifitas suatu pembelajaran dalam pemahaman konseptual. Uji statistik yang dilakukan dalampenelitianiniadalah uji normalitas, uji homogenitas dan Uji hipotesis dengan uji perbedaan dua rerata.

\section{HASIL DAN PEMBAHASAN}

Pertama, skor rata-rata pretes-postes motivasi belajar kelas eksperimen terdiri dari 80,97 terwakili sebanyak $74 \%$ pesertadidik untuk rata-rata skor pretes sedangakan pada skor postes diperoleh skor sebesar 89,40 terwakili oleh $81 \%$ peserta didik. Berdasarkan hasil uji normalitas diperoleh nilai pre tes motivasi belajar kelas eksperimen dengan nilai signifikansi $p$-value $=0,200$ sehingga $p$-value $>\alpha$, maka berdasarkan hasil yang ada diputuskan bahwa sampel berasal dari populasi yang berdistribusi normal. Untuk postes dengan nilai signifikansi $p$-value $=$ 0,006 , sehingga $p$-value $<\alpha$, dengan demikian sampel yang ada tidak berasal dari populasi yang berdistribusi normal dan uji homogenitas nilai prestes-postes motivasi belajar kelas eksperimen dengan nilai signifikansi $p$-value $=0,015$, sehingga $p$-value $<\alpha$ maka dengan demikian sampel tidak berasal dari populasi yang homogen. Karena persyaratan normalitas dan homogenitas data pretespostes motivasi belajar kelas eksperimen tidak terpenuhi maka pengujian dilanjutkan dengan uji non parametrik dengan nilai yang diperoleh signifikan $p$-value $=0,000$, sehingga $p$-value $<\alpha$ dan hal ini berarti $\mathrm{H}_{0}$ ditolak yang artinya skor postes motivasi belajar kelas eksperimen lebih baik dari skor pretes. N-gain motivasi belajar pada kelas eksperimen dengan normalisasi gain sebesar 0,28 . Jika dibandingkan dengan indeks gain $\mathrm{g} \leq 0,30$ maka peningkatan motivasi belajar kelas eksperimen dikategorikan rendah. Pembahasan motivasi belajar kelas eksperimen dirujuk pada pemaparan data hasil pretes-postes. Hasil pemaparan data menunjukkan bahwa Berdasarkan hasil penelitian maka dapat disimpulkanm bahwaterdapat perbedaan motivasi belajar peserta didik antara sebelum dan sesudah perlakuan pada kelas eksperimen yang menggunakan media pembelajaran berbasis TIK. Berdasarkan skor pretes-postes, diketahui peningkatan motivasi belajar kelas eksperimen dikategorikan rendah. Hasil penelitian ini didukung oleh hasil penelitian Heafner, T (2004:49), Saiful Bahri (2011:146), dan Joshua E. Susskind (2006:9) menyatakan bahwa media pembelajaran berbasis TIK berpengaruh terhadap motivasi belajar pesertadidik.Kedua, pengujian statistik data pretes-postes motivasi belajar yang dilakukan terhadap kelas kontrol dengan 33 pesertadidik. Berdasarkan hasil pengujian statistik deskriptif terdapat hasil pretes-postes motivasi belajar kelas kontrol informasi bahwa skor rata-rata pretes-postes motivasi belajar kelas kontrol terdiri dari 81,67 (74\%) untuk rata-rata skor pretes sedangkan pada rata-rata skor postes diperoleh skor sebesar 88,06 (80\%). Hasil uji normalitas motivasi belajar kelas kontrol dengan nilai signifikansi $p$-value $=0,082$, 
sehingga $p$-value $>\alpha$, maka sampel berasal dari populasi yang berdistribusi normal dan untuk postes dengan nilai signifikansi $p$-value $=0,010$, sehingga $p$-value $<\alpha$. Dengan demikian sampel tidak berasal dari populasi yang berdistribusi normal. Uji Homogenitas dengan nilai signifikansi $p$-value $=0,001$, sehingga $p$-value $<\alpha$, dengan demikian sampel tidak berasal dari populasi yang homogen. Uji Mann-Whitney prestes-postes motivasi belajar kelas kontrol bernilai signifikansi $p$-value $=0,002$, sehingga $p$-value $<\alpha$ dan hal ini berarti $\mathrm{H}_{0}$ ditolak yang artinya bahwa skor postes motivasi belajar kelas kontrol lebih baik dari skor pretes. Efektivitas pengaruh dari penggunaan media grafis terhadap kelas kontrol. Hasil perhitungan menunjukkan rata-rata gain yang ternormalisasi terhadap skor pretes-postes motivasi belajar kelas kontrol dengan normalisasi gain sebesar 0,20. Jika dibandingkan dengan indeks gain $\mathrm{g} \leq 0,30$ maka peningkatan motivasi belajar kelas eksperimen dikategorikan rendah. Berdasarkan n-gain motivasi belajar kelas kontrol maka dapat disimpulkan bahwaterdapat perbedaan motivasi belajar peserta didik antara sebelum dan sesudah perlakuan pada kelaskontrol yang menggunakan media grafis. Berdasarkan skor pretes-postes, diketahui peningkatan motivasi belajar kelas kontrol dikategorikan rendah.Ketiga, pengujian statistik data skor peningkatan motivasi belajar yang dilakukan terhadap kelas eksperimen-kontrol. Berdasarkan hasil pengujian statistik deskriptif (Tabel 10) terdapat hasil skor peningkatan motivasi belajar memberikan informasi bahwa skor rata-rata peningkatan motivasi belajar kelas eksperimen sebesar $8,43(91 \%)$ dan untuk kelas kontrol sebesar 6,39 (93\%). Berdasarkan rekapitulasi uji normalitas diperoleh nilai peningkatan motivasi belajar kelas eksperimen dengan nilai signifikansi $p$-value $=0,043$, sehingga $p$-value $<\alpha$ maka dengan demikian sampel tidak berasal dari populasi yang berdistribusi normaldan untuk kelas kontrol dengan nilai signifikansi $p$-value $=0,200$, sehingga $p$-value $>\alpha$ maka dengan demikian sampel berasal dari populasi yang berdistribusi normal. Berdasarkan rekapitulasi uji homogenitas diperoleh nilai peningkatan motivasi belajar kelas eksperimen-kontrol dengan nilai signifikansi $p$-value $=0,666$, sehingga $p$-value $>\alpha$ maka dengan demikian sampel berasal dari populasi yang homogen. Berdasarkan hasil uji Mann-Whitney diperoleh rata-rata peningkatan motivasi belajar kelas eksperimen-kontrol bernilai signifikansi $p$-value $=0,436$, sehingga $p$-value $>\alpha$ dan hal ini berarti $\mathrm{H}_{0}$ diterima yang artinya ada tidak ada perbedaan ratarata antara peningkatan dari motivasi belajar kelas eksperimen-kontrol. Rata-rata peningkatan motivasi belajar antar kelas eksperimen dan kontrol memberikan informasi bahwa rata-rata peningkatan motivasi belajar kelas eksperimen dengan normalisasi gain sebesar 0,28 dan rata-rata peningkatan motivasi belajar kelas kontrol dengan normalisasi gain sebesar 0,20. Jika dibandingkan dengan indeks gain $\mathrm{g} \leq 0,30$ maka peningkatan motivasi belajar kelas eksperimen dan kelas kontrol berada pada kategori yang sama yaitu dikategorikan rendah. Berdasarkan N-Gain motivasi belajar kelas eksperimen-kontrol maka dapat disimpulkan bahwa tidak berdasarkan hasil penelitian maka dapat disimpulkan bahwatidak terdapat perbedaan peningkatan motivasi belajar peserta didik antara kelas eksperimen yang menggunakan media pembelajaran berbasis TIK dengan kelas kontrol yang menggunakan media grafis. Empat, hasil pemaparan data menunjukkan bahwa tidak terdapat perbedaan peningkatan motivasi belajar antara kelas eksperimen yang menggunakan media pembelajaran berbasis TIK dan kelas kontrol yang menggunakan media grafis dalam PBM dan peningkatan motivasi dari kelas eksperimenkontrol sama-sama dikategorikan rendah. Rendahnya peningkatan motivasi belajar 
antara kelas eksperimen-kontrol menunjukkan rendahnya pengaruh dari penggunaan media pembelajaran berbasis TIK dikelas eksperimen dan penggunaan media grafis dikelas kontrol. Kondisi ini karena motivasi belajar pesertadidik kelas eksperimen-kontol termasuk dalam kategori sangat baik (mengacu pada Arikunto, 2012:232). Media pembelajaran berbasis TIK berpengaruh rendah terhadap peningkatan motivasi belajar peserta didik disebabkan oleh rancangan media tidak dimanfaatkan sesuaikan dengan kebutuhan motivasi belajar pesertadidik dari value components, expecrancy components, dan affective components. Sedangkan rendahnya pengaruh media grafis terhadap peningkatan motivasi belajar peserta didik disebabkan oleh rancangan media yang tidak dibuat secara spesifik untuk memfasilitasi kebutuhan motivasi belajar dari value components, expectancy components, dan affective components dengan baik. Untuk menunjang kebermanfaatan fasilitas tersebut maka pendidik harus mampu mengintegrasi strategi motivasi kedalam materi pelajaran dengan kemampuan komunikasi yang baik agar pesan yang disampaikan dapat menyamakan persepsi dan memotivasi pesertadidik. Rendahnya pengaruh penggunaan media berbasis TIK dan media grafis terhadap motivasi belajar pesertadidik akan terlihat melalui PMB dikedua kelas. Berdasarkan lembar observasi aktivitas pemebelajaran dan pengamatan maka penyebab rendahnya peningkatan motivasi belajar pesertdidik kelas eksperimen-kontrol selain motivasi pesertadidik yang dalam keadaan sangat baik kondisi ini juga dipengaruhi oleh kurang maksimalnya pengintegrasian media kedalam penerapan strategi motivasi seperti memberikan hadiah, pujian, nilai, hukuman, kontrol terhadap kinerja akademik, membuat mereka tertantang, membuat rasa ingin tahu mereka muncul, menumbuhkan minat mereka, dan menumbuhkan keyakinan mereka sehingga komponen motivasi intrinsic goal orientation, extrinsic goal orientation, task value, control of learning beliefs, self-efficacy for learning and performance dapat terpenuhi.Berkaitan dengan pengaruh media pembelajaran berbasis TIK terhadap motivasi belajar peserta didik maka berbagai fitur seperti video, gambar, suara, teks, grafik, dan fasilitas lainnya harus digunakan dengan maksimal agar tepat guna dan berdaya guna. Berdasarkan hasil pengamatan selama penelitian dalam PBM kelas eksperimen yang menggunakan media pembelajaran berbasis TIK yaitu power point, maka peneliti menemukan beberapa hal terkait dengan upaya meningkatkan motivasi belajar peserta didik melalui media berbasis TIK. Upaya meningkatkan motivasi belajar pesertadidik dalam PBM untuk value components, maka pendidik dapat melakukannya dengan membuat slide ppt yang berisi tujuan pembelajaran dengan memanfaatkan video atau gambar-gambar yang sesuai dengan materi. Pendidik harus menjelaskan hubungan antara gambar atau video dengan materi pelajaran dan memberi penekanan bahwa materi tersebut penting untuk diketahui. Diharapkan perlakuan tersebut dapat membuat peserta didik merasa tertantang, penasaran, dan memunculkan rasa ingin tahu karena menurut Howey, S. C (2008) rasa tertantang, penasaran, dan rasa ingin tahu dapat memunculkan motivasi. Partisipasi peserta didik dalam PBM dapat diupayakan dengan media ppt dengan metode PBL. Menyajikan peramasalahan kepada pesertadidik dan mengarahkannya untuk mengkontruksi pemahaman dan menemukan jawaban permasalahan yang ada melalui video atau animasi yang ditayangkan karena menurut Hamzah (2009:27) hal ini dapat memunculkan motivasi pesertadidik. Selain itu, slide ppt yang dibuat interaktif dengan cara mengosongkan beberapa kalimat penting dalam slide dan mengarahkan agar dijawab oleh peserta didik, hal ini diharapkan dapat membangun persaingan positif dalam hal 
menjawab pertanyaan tersebut. Diperlukan juga skor atau nilai dari setiap pertanyaan untuk peserta didik yang berhasil menjawab pertanyaan yang diberikan. Dengan demikian peserta didik merasakan manfaat dari keterlibatannya berupa nilai yang didapat dan menurut Howey, S C (2008) hal ini merupakan strategi untuk memotivasi peserta didik. Mengupayakan peningkatan motivasi belajar peserta didik untuk expectancy components dan affective components melalui media ppt maka secara sederhana dan mudah pendidik dapat melakukannya dengan memanfaatkan video yang dapat diperoleh dari www.youtube.com atau media lainnya. Sebaiknya video yang akan ditayangkan dihubungkan dengan proses belajar peserta didik dan bermanfaat untuk meningkatkan kepercayaan diri peserta didik, memotivasi pesertadidik untuk sungguhsunguh dalam meraih kesuksesan, dan motivasi akan pentingnya sebuah kerja keras serta kesungguhan. Ditayangkannya video motivasi dapat dilakukan pada waktu awal PBM atau waktu akhir PBM dan akan lebih baik jika ditambah penguatan oleh pendidik melalui komunikasi verbal karena menurut teori dual coding yang dipopulerkan oleh Pavio (Ahmad, R M dan Yahya, B. (2008:183) menyatakan bahwa pemikiran manusia diproses melalui komunikasi verbal dan non verbal. Pemanfaatan video untuk meningkatkan motivasi belajar peserta didik untuk expectancy components dan affective components bertujuan untuk mengkondisikan lingkungan baru bagi pesertadidik yaitu lingkungan yang memberikan nilai-nilai kesungguhan, kesuksesan, dan kerja keras sehingga pola pikir dan prilaku peserta didik terpengaruh oleh nilai-nilai yang ada dan ini sesuai dengan konsep skemata Piaget (Baharuddin dan Wahyuni, E. N, 2007: 118) yang menganggap bahwa manusia akan selalu berusaha menyesuaikan diri dengan lingkungannya sehingga menghasilkan sebuah perilaku. Berdasarkan analisis data dan hasil pengamatan maka dapat dinyatakan bahwa media pembelajaran berbasis TIK dalam bentuk media presentasi microsoft power point dapat berpengaruh lebih baik terhadap peningkatan motivasi belajar pesertadidik jika berbagai fitur seperti video, gambar, suara, animasi dari media tersebut disesuaikan dengan kebutuhan motivasi belajar pesertadidik dari value components, expecrancy components, dan affective components.Berdasarkan hasil pengamatan selama empat kali pertemuan dalam PBM kelas kontrol yang menggunakan media grafis dalam pembelajaran, maka peneliti menemukan beberapa hal terkait dengan upaya meningkatkan motivasi belajar peserta didik melalui media grafis. Mengupayakan munculnya motivasi belajar pesertadidik dalam PBM untuk value components, maka pendidik dapat melakukannya dengan menampilkan komik sebagai bentuk dari media grafis yang menerapkan suatu cerita dengan ekspresi dan visualisasi dengan penekanan yang kuat akan pentingnya sebuah materi pelajaran untuk diketahui karena menurut Daryanto (2011:116) media ini dapat membuat keterlibatan secara emosional sehingga diharapkan ilustrasi yang muncul dari komik dapat menarik perhatian peserta didik sehingga memunculkan rasa penasaran dan rasa ingin tahu karena menurut Howey, S. C (2008) penasaran dan rasa ingin tahu dapatmemunculkan motivasi. Mengupayakan partisipasi peserta didik dalam PBM dapat diupayakan dengan media grafis yang menyajikan bagan tertutup atau hidden chart dengan model bagan pohon. Bagan tertutup membantu pendidik menyajikan pesan dalam pembelajaran dengan model sebuah pohon yang terdiri dari cabang dan ranting sehingga menjadi sebuah skema dari pesan yang akan disampaikan. Setiap pesan kemudian ditutup dengan potongan kertas yang mudah untuk dilepas. Pada saat penyajian pendidik dapat mengupayakan partisipasi pesertadidik dengan meminta mereka untuk menjawab skema yang sebelumnya ditutup kertas, setiap jawaban harus diberi nilai dan 
penghargaan, dengan perlakuan ini pesertadidik merasakan manfaat dari keterlibatannya. Hal ini diharapkan dapat membangun persaingan positif dan memenuhi kebutuhan pesertadidik akan nilai dan menurut Howey, S C (2008) upaya seperti ini merupakan strategi untuk memotivasi peserta didik. Mengupayakan peningkatan motivasi belajar peserta didik untuk expectancy components dan affective components melalui media grafis maka pendidik dapat memanfaatkan media grafis dalam bentuk poster yang berisi peringatan, ajakan, anjuran, maupun cerita kreatif yang terintegrasi dalam PBM. Penggunaan poster ini dapat disisipkan diawal dan diakhir PBM dengan variasi gambar dilengkapi penekanan kalimat seperti 'rajin pangkal pandai, malas pangkal bodoh' kemudian dikomunikasikan oleh pendidik dengan penuh makna maka diharapkan hal ini membuat peserta didik percaya bahwa upaya mereka untuk belajar akan membuat perbedaan dalampembelajaran mereka karena Arif, S. S. et al (2011:46) dan Daryanto (2011:117) berpendapat bahwa poster mampu mempengaruhi persepsi orang yang melihatnya hingga melakukan sesuatu sesuai pesan yang didapatnya dari poster tersebut. Jika keyakinan diri peserta didik muncul maka ini memungkinkan perubahan yang lebih baik sehingga mengurangi tingkat kekhawatiran pesertadidik dan menurut Howey, S C (2008) keyakinan diri merupakan bagian yang dapat menumbuhkan motivasi. Berdasarkan analisis data dan hasil pengamatan maka dapat dinyatakan bahwa media grafis dapat berpengaruh lebih terhadap peningkatan motivasi belajar peserta didik jika menggunakan media grafis dengan bentuk media komik, poster, dan bagan tertutup dalam ukuran yang dapat terbaca oleh semua peserta didik. Berbagai bentuk media tersebut sebaiknya disesuaikan dengan kebutuhan motivasi belajar pesertadidik dari value components, expecrancy components, dan affective components.

\section{KESIMPULAN}

Berdasarkan hasil penelitian maka dapat disimpulkanm bahwa:Pertama, terdapat perbedaan motivasi belajar peserta didik antara sebelum dan sesudah perlakuan pada kelas eksperimen yang menggunakan media pembelajaran berbasis TIK. Berdasarkan skor pretes-postes, diketahui peningkatan motivasi belajar kelas eksperimen dikategorikan rendah. Kedua, terdapat perbedaan motivasi belajar peserta didik antara sebelum dan sesudah perlakuan pada kelaskontrol yang menggunakan media grafis. Berdasarkan skor pretes-postes, diketahui peningkatan motivasi belajar kelas kontrol dikategorikan rendah. Ketiga, tidak terdapat perbedaan peningkatan motivasi belajar peserta didik antara kelas eksperimen yang menggunakan media pembelajaran berbasis TIK dengankelaskontrol yang menggunakan media grafis. Berdasarkan skor pretes-postes, diketahui peningkatan motivasi belajar kelas eksperimen dan kelas kontrol sama-sama dikategorikan rendah. Media pembelajaran merupakan kompenen yang penting dalam keterlaksanaan proses pembelajaran sehingga sudah menjadi keharusan bagi pendidik untuk mampu memilih dan merancang media yang sesuai dengan kebutuhan pembelajaran. Media pembelajaran berbasis TIK merupakan sarana penunjang pembelajaran. Berdasarkan pertimbangan akan kemudahan merancang dan kemudahan menggunakan maka media berbasisi TIK dalam bentuk media presentasi microsoft powerpoint dapat menjadi pilihan bagi pendidik. Media ini adalah media yang sederhana dan fasilitas yang ada didalamnya sama dengan fasilitas yang dapat digunakan dalam media lainnya seperti multimedia interaktif.Efektifitas pembelajaran dengan menggunakanmedia pembelajaran microsoft powerpoint sebaiknya dilengkapi dengan sarana dan prasarana yang menunjang seperti LCD preyktor yang dipasang permanen disetiap kelas sehingga tidak mempengaruhi waktu belajar. Pendidikjuga harus melengkapi 
diri dengan laser pointer sehingga pendidik tidak hanya duduk didepan laptop ketika menjalankan program microsoft powerpoint. Pemanfaatan media akan lebih baik jika diadakah pelatihan khusus bagi pendidik dalam merancang media pembelajaran yang kreatif dan inovatif, pelatihan ini dapat diadakan dalam ruang lingkup MGMP agar spesifikasi pelatihan dapat dikhususkan untuk bidang tertentu. Pelatihan ini juga dapat dilakukan dalam lingkup sekolah agar fasilitas yang disediakan sekolah dapat dimanfaatkan dengan maksimal untuk proses pembelajaran disekolah.Hasil penelitian ini bukanlah penelitian yang dapat digeneralisasikan untuk semua mata pelajaram, tingkatan sekolah, dan pendidik. Perlu adanya penenlitian lanjutan yang berkaitan dengan pengaruh media terhadap kemampuan spasial peserta didik sehingga kajian keilmuan tentang media pembelajaran akan lebih spesifik.

\section{DAFTAR PUSTAKA}

Ahmad RM dan Yahya B. (2008). "Gaya Kognitif dan Visualisasi Pelajar melalui perisian multimedia”. Masalah Pendidikan, 31, (1), 181-192.

Arikunto, S. (2012). Dasar-Dasar Evaluasi Pendidikan. Edisi dua. Jakarta: Bumi Aksara.

Arif-S, Sadiman. et al. (2011). Media Pendidikan; Pengertian, Pengembangan, dan Pemanfaatannya(Cetakan ke-15). Jakarta: Rajawali Pers.

Baharuddin dan Wahyuni, E. N. (2008). Teori Belajar dan Pembelajaran (Cetakan ke-3). Jogjakarta: Ar-Ruzz Media.

Daryanto. (2011). Media Pembelajaran. Bandung: Satu Nusa.

Hamzah B.Uno. (2009). Teori Motivasi dan Pengukurannya (Cetakan ke-5). Jakarta: Bumi Aksara.

Heafner, T. (2004). "Using Technology to Motivate Students to Learn Social Studies". Contemorary Issuesin Technology and Teacher, 4 (1), 42-53.

Howey, S.C. (2008). Factors in student motivation. [Online]. Tersedia: http://www.nacada.ksu.edu/Resources/ Clearinghouse/View-Articles/Motivation-a620.aspx [diakses 22 Januari 2013].

Joshua E. S. (2006). "Limits of PowerPoint's Power: Enhancing Students' Self-Effcacy And Attitudes But Not Their Behavior." Computers \& Education. 1-12.

Mwalongo, A. (2011). “Teachers' Perceptions About ICTFor Teaching, Professional Development, Administration and Personal Use". International Journal of Education and Development Using Information and Communication Technology (IJEDICT). 7, (3), 36-49.

Pintrich, PR and V. De Groot. (1990). "Motivation and Self-Regulated Learning Component of Classroom Academic Performance". Journal of Educational Psychology, 82 (1), 33-40.

Rusman, D. K. dan Cepi, R. (2011). Pembelajaran Berbasis Teknologi Informasi dan Komunikasi. Jakarta: Rajawali Pers. 